ники следующие сорта: по высоте стебля Флагман 5, Флагман 9 и Казанец; по многоплодности на узлах Батрак и Gousses; по количеству семян в бобе и мелкосемянности - Ямальский и Губернатор; по засухоустойчивости -Флагман 7 и Флагман 9.

\section{СПИСОК ЛИТЕРАТУРЫ}

1. Башарин Г.П. История земледелия в Якутии. Т.2. Якутск: Кн. изд-во, 1989. - 412 с.

2. Данилов А.Н., Летучий А.В., Пимонов К.И. Агрохимическая оценка применения удобрений при возделывании усатых форм гороха // Аграрный научный журнал. 2015. - № 11. - C. 6-9.

3. Доспехов Б.А. Методика полевого опыта. - М., 1985. - $244 \mathrm{c}$.

4. Конюхов Г.И., Неустроев А.Н. Горох в Якутии. Задачи селекции // Апробация. - 2014. - № 2. - С. 17-23.
5. Методические указания по изучению мировой коллекции ВИР. - Л., 1985. - С. 24.

Неустроев Алексей Николаевич, научный сотрудник лаборатории селекции и семеноводства зерновых и кормовых культур, Якутский научно-исследовательский институт сельского хозяйства имени М.Г. Сафронова. Россия.

Алексеева Валентина Ивановна, канд. с.-х. наук, ведущий научный сотрудник лаборатории селекции и семеноводства зерновых и кормовых культур, Якутский научноисследовательский институт сельского хозяйства имени М.Г. Сафронова. Россия.

677001, г. Якутск, ул. Бестужева-Марлинского, 23/1.

Тел.: (4112) 21-45-74.

Ключевые слова: горох посевной; отбор; неполегающий; высота; многоплодность; мелкосемянность; продуктивность.

\title{
INITIAL MATERIAL OF PEAS (PISUM SATIVUM L.) IN CONDITIONS OF CENTRAL YAKUTIA
}

Neustroev Alexey Nikolaevich, Researcher of the laboratory of selection and seed-growing of grain and forage crops, Yakut Scientific Research Institute of Agriculture named after M.G. Safronov. Russia

Alekseeva Valentina Ivanovna, Candidate of Agricultural Sciences, Researcher of the Laboratory of Selection and Seed Growing of Grain and Forage Crops, Yakut Research and Development Institute of Agriculture. M.G. Safronov. Russia

Keywords: peas; selection; source; 1000 grain weight.

The article presents the results of study the varieties of peas from the world collection of the N.I. Vavilov Research Institute of Plant Industry (VIR). It has been carried out to select the source material for creating variety for single-phase harvesting and adapted to the conditions of Yakutia. The height of the stem was measured during the maturation phase of the seeds. On this basis, 3 varieties Flagman 5 , Flagman 9 and Kazanets are distinguished. A large number of beans in the plant is noted in varieties Flagman 5, Gubernator, Gousses; multiplicity at the nodes in varieties Batrak and Gousses; high number of seeds in varieties Yamalsky 5, Flagman 9, Gubernator, Demos. High productivity was noted in varieties Flagman 7, Gubernator, Flagman 5, Flagman 9, Gousses, Omskiy 9. Shustrik, Multik, Madonna and Demon are less resistant (3 points) to drought varieties, Flagman 7 and Flagman 9 are of high resistance (7 points), and 6 varieties are of average drought resistance (5 points).

\section{МОНОСАХАРИДНЫЙ СПЕКТР АРАБИНОКСИЛАНОВОЙ ФРАКЦИИ ЗЕРНА РАЗНЫХ ГЕНОТИПОВ ОЗИМОЙ РЖИ}

\author{
ПОНОМАРЕВА Мира Леонидовна, ТатНИИСХ ФИЦ КаЗНЦ РАН \\ ПОНОМАРЕВ Сергей Николаевич, ТатНИИСХ ФИЦ КазНЦ РАН \\ МАННАПОВА Гульназ Сулеймановна, ТатНИИСХ ФИЦ КазНЦ РАН \\ ГИЛЬМУЛЛИНА Лилия Фирдависовна, ТатНИИСХ ФИЦ КазНЦ РАН
}

\begin{abstract}
Проведен анализ содержания и моносахаридного состава углеводной фракции ржаного шрота различных сортов с использованием метода высокоэффективной анионообменной хроматографии. Доминирующим компонентом была глюкоза, примерно в равных пропорииях обнаружены арабиноза, ксилоза и галактоза. Установлено, ито в результате работы экзо-ферментов зерна ржи происходит частичная деградация арабиноксиланов и крахмала в начале водной экстракции при температуре $30{ }^{\circ} \mathrm{C}$. Водные экстракты зернового шрота содержали от 52 до 74 \% углеводов в олиго- и полимерной форме. Основываясь на содержании моносахарида ксилозы, сорта ржи Огонек, Подарок и Марусенька охарактеризованы как низкопентозановые, а Татарская 1, Радонъ и Памяти Кунакбаева как высокопентозановые (9-11 и 14-16 мг ксилозы на 1 мл экстракта соответственно).
\end{abstract}

введение. Углеводы ржаной муки представлены в основном крахмалом и отчасти некрахмальными полисахаридами (НКП). При сравнении с пшеницей гетерополисахариды ржи, чаще именуемые в литературе пентозанами, содержатся в большем количестве - от 2,5 до 7,4 \% сухого вещества зерна. При близком общем количестве пентозанов в зерне пшеницы и ржи количество водорастворимых пентозанов у ржи примерно в 2 раза больше, степень полимеризации и молекулярная масса существенно выше, а структура более разветвленная [4]. В качестве продуктов гидролиза пентозанов в основном получаются пентозы (D-ксилоза, L-арабиноза). В их состав входит также глюкоза (до 20 \%) и в очень небольших количествах фруктоза и галактоза [10]. Поэтому в специальной научной литературе для их обозначения чаще используется термин «арабиноксиланы» (АК).
В зерне ржи имеются ферменты эндогенные пентозаназы - арабинозидазы, эндо- и экзоксиланазы, ксилобиазы, гидролизующие высокомолекулярные компоненты гетерополисахаридов, в результате чего повышается количество водорастворимых пентозанов [8]. Основной особенностью АК зерна ржи является их способность легко набухать в воде, образуя чрезвычайно вязкие растворы, при этом объем при гидратации увеличивается почти в 10 раз. Вязкостные свойства пентозанов ржаной муки возрастают при кратковременном ее хранении при температурах от 18-20 до $40{ }^{\circ} \mathrm{C}$ [9].

Арабиноксиланы ржи играют важнейшую роль при переработке зерна. Значение АК в технологии приготовления ржаного теста и хлеба велико, но недостаточно выяснено. Наличие в ржаных некрахмальных полисахаридах разветвленной арабиноксила- 
новой фракции, высокая степень их полимеризации способствуют образованию комплексов с белками и крахмалом в ржаной муке, особенно в ржаном тесте. Существует мнение, что именно образование в присутствии воды комплекса белков с арабиноксилановой фракцией является главной причиной невозможности отмывания клейковины и образования клейковинного каркаса в ржаном тесте [1]. Считается, что у ржи именно пентозаны функционируют аналогично клейковине пшеницы во время процесса ферментации путем уменьшения диффузии $\mathrm{CO}_{2}$ из теста, способствуют удержанию газа и повышению общего объема буханки хлеба. Доказано, что водоудерживающая способность теста и свежесть хлеба из ржи в значительной степени зависят от содержания в нем некрахмальных полисахаридов, большинство из которых являются полимерами ксилозы и арабинозы, т. е. пентозанов [6].

Имеющиеся данные позволяют считать, что эти вещества существенно влияют на структурно-механические свойства ржаного теста, на его консистенцию и газоудерживающую способность, на амилолиз и клейстеризацию крахмала в процессе выпечки хлеба, а также на такие показатели качества хлеба, как его объем, структура, реологические свойства мякиша и даже скорость черствения. Увеличение содержания АК при тестоведении приводит к большей абсорбции воды, которая влияет на замес теста и значительно улучшает общее качество хлебобулочных изделий $[3,10]$.

Другим несомненным достоинством некрахмальных полисахаридов являются разнообразные физиологически полезные свойства: улучшение перистальтики кишечника, возникновение ощущения сытости и т.д. Поэтому данная группа химических соединений получила обобщающее название пищевые (диетические) волокна, потребление которых связано с такими полезными для здоровья факторами, как пробиотическая активность, снижение риска различных заболеваний, улучшение обмена липидов и жиров, повышение иммунитета и противоопухолевая активность [7]. Наоборот, негативный зоотехнический эффект присутствия большого количества пентозанов в зерне ржи связывается с расстройством пищеварения и снижением переваримости питательных веществ у животных. Антипитательные свойства пентозанов отрицательно сказываются на вкусовых свойствах и степени усвоения кормов. Поэтому АК рассматривают как главный фактор, ограничивающий использование ржи в кормлении, особенно для животных с однокамерным желудком и птицы [11]. Снижение их количества, в первую очередь водорастворимой фракции, будет способствовать улучшению фуражных свойств зерна ржи.

Чаще всего содержание пентозанов определяют посредством изучения признака вязкости водного экстракта (BВЭ) зернового шрота, который стал важным экспериментальным показателем как для определения хлебопекарных качеств ржи, так и для выявления кормовых достоинств зерна. Показано наличие высокой корреляции между содержанием водорастворимых пентозанов (арабиноксиланов) и вязкостью экстракта зерна ржи $[1,5]$.

Цель данного исследования - определить особенности моносахаридного состава арабиноксиланов, содержащихся в шроте разных генотипов озимой ржи.

Методика исследований. Исследовали 6 российских сортов озимой ржи, различающихся по содержанию пентозанов [2]. Изучаемые сорта выращивались в полевых опытах на серых лесных почвах Предкамской зоны Республики Татарстан (землепользование ФИЦ
КазНЦ РАН). Размол зерна урожая 2015 и 2016 гг. для получения шрота проводили на лабораторной мельнице Laboratory mill 3100 (Perten Instruments, Германия). Водную экстракцию проводили при температуре $30^{\circ} \mathrm{C}$. Моносахаридный анализ (разделение и детектирование моносахаридов) осуществляли при помощи высокоэффективной анионообменной хроматографии (система DX-500, Dionex, USA) на колонке CarboPac PA-1 (4×250 мм, Dionex, USA) с использованием электрохимического детектора в режиме пульс-амперометрии (ED 40, Dionex, USA). Количественную оценку содержания отдельных моносахаридов в образцах осуществляли с помощью калибровочных кривых, предварительно построенных для индивидуальных моносахаридов при помощи программного обеспечения PeakNet.

Результаты исследований. Суммарное содержание углеводов, полученных в результате водной экстракции шрота различных сортов ржи, колебалось от 41 до 53 мг/мл, т.е. суспензии представляли собой 4-5\%-е (по массе) растворы углеводов в моно- и полисахаридной формах (рис. 1). Различия, выявленные между изучаемыми сортами, были не достоверны.

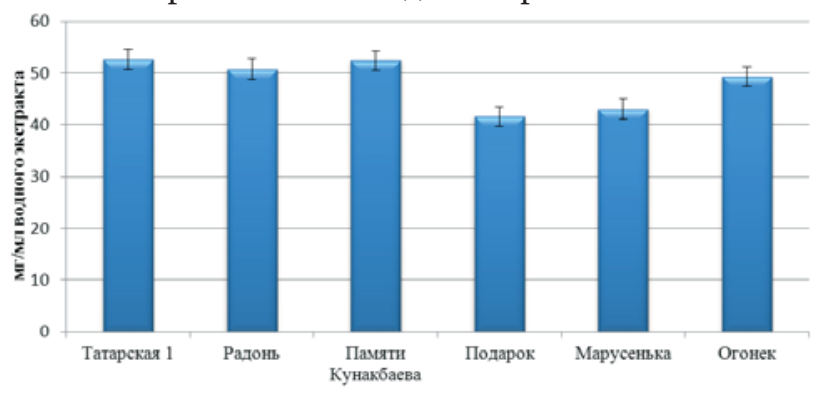

Рис. 1. Содержание углеводов в водных экстрактах ирота различных сортов ржи

Углеводы в моносахаридной форме составляли от 24 до 47 \% от всех водорастворимых углеводов ржаного шрота (рис. 2). Глюкоза, по-видимому, «крахмального» происхождения во всех случаях была доминирующим компонентом.

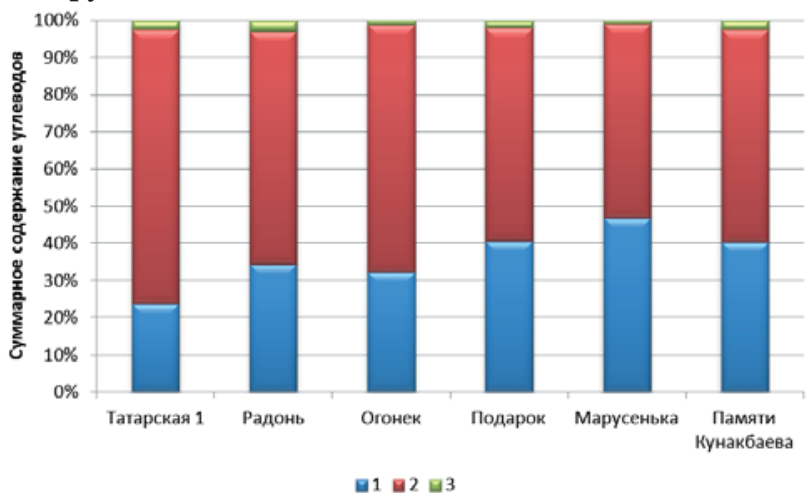

Рис. 2. Соотношение углеводов в водном экстракте и осадке шрота сортов озимой ржи: 1 - содержание моносахаридов в водорастворимой фракиии; 2 - содержание олигои полисахаридов в водорастворимой фракиии;

3 - содержание углеводов в осадке водной суспензии

Присутствие в примерно равных пропорциях арабинозы, ксилозы и галактозы указывало на частичную деградацию арабиноксиланов. Галактоза могла входить в состав арабиногалактанов, пектиновых веществ, хотя в этом случае в пробах должна была бы присутствовать и галактуроновая кислота как типичный компонент остова пектиновых веществ. Наличие моносахаридов в водном экстракте шрота, вероятно, является результатом работы экзо-ферментов зерна ржи в ходе водной экстракции. Следует отметить, что наибольшей активностью этих ферментов характеризуются сорта Марусенька и Памяти Кунакбаева, а наименьшей - сорт Татарская 1. 
Водные экстракты шрота ржи различных сортов содержали 23-40 мг/мл углеводов в олиго- и полимерной формах, что составляло от 52 до $74 \%$ от всех экстрагированных углеводов. В состав олиго- и полимерных углеводов, экстрагированных из ржаного шрота, также входили ксилоза, глюкоза, арабиноза и галактоза, что указывает на присутствие в этой фракции олигомерных фрагментов и полимеров крахмала, арабиноксилана и, возможно, смешанно-связанных глюканов.

Важно отметить, что содержание глюкозы в полимерной форме сопоставимо с содержанием ксилозы (рис. 3), т.е. водная экстракция ржаного шрота высвобождает сопоставимые количества крахмала и смешанно-связанных глюканов и арабиноксиланов. Соотношение арабиноза/ксилоза, которое обычно используется для характеристики степени замещения арабиноксиланов, для полимеров водного экстракта ржаного шрота составляло около 0,3, то есть из 10 остатков ксилозы в остове только 3 могут быть замещены арабинозой.

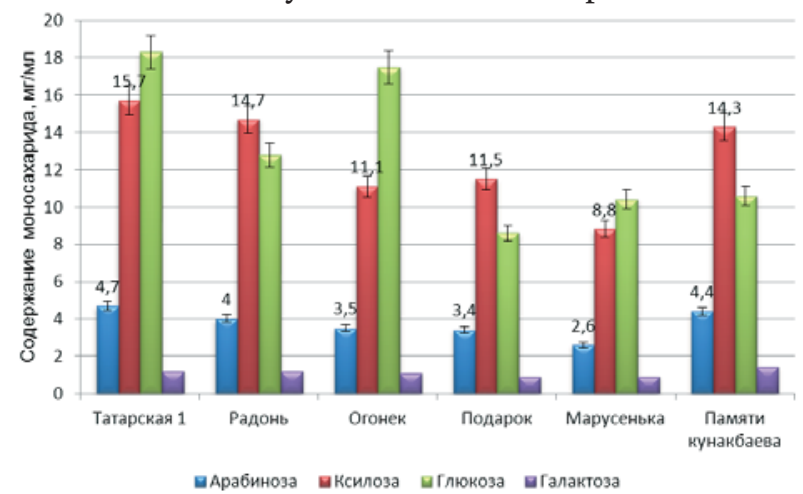

Рис. 3. Содержание моносахаридов в составе олигои полисахаридов водорастворимой фракции ржаного шрота

Заключение. Нами был проведен анализ количественного и качественного содержания моносахаридного состава углеводной фракции ржаного шрота различных сортов с использованием метода высокоэффективной анионообменной хроматографии высокого давления. Доминирующим компонентом была глюкоза, в примерно равных пропорциях обнаружены арабиноза, ксилоза и галактоза.

Установлено, что в результате работы экзо-ферментов зерна ржи происходит частичная деградация арабиноксиланов и крахмала в начале водной экстракции при температуре $30{ }^{\circ} \mathrm{C}$. Водные экстракты зернового шрота содержали от 52 до 74 \% углеводов в олиго- и полимерной форме. Основываясь на содержании моносахарида ксилозы, сорта ржи Огонек, Подарок и Марусенька охарактеризованы как низкопентозановые, а Татарская 1, Радонь и Памяти Кунакбаева как высокопентозановые (9-11 и 14-16 мг ксилозы на 1 мл экстракта соответственно).

\section{СПИСОК ЛИТЕРАТУРЫ}

1. Гончаренко А.А. Актуальные вопросы селекции озимой ржи. - М., 2014. - 372 с.

2. Изучение содержания пентозанов в зерне популяционных сортов озимой ржи различными методами // Достижения науки и техники АПК. - 2016. - Т. 30. - № 12. - С. 10-13.

3. Фенотипическая оценка содержания пентозанов в ржаном шроте методом определения вязкости водного экстракта / М.Л. Пономарева [и др.] // Достижения науки и техники. - 2015. - Т. 29. - № 11. - С. 32-35.

4. Bederska-Łojewska D., Światkiewicz S., Arczewska-Wtosek A., Schwarz T. Rye non-starch polysaccharides: their impact on poultry intestinal physiology, nutrients digestibility and performance indicesa review // Annals of Animal Science, 2017, T. 17, No. 2, P. 351-369.

5. Cyran M.R., Ceglinska A. Genetic variation in the extract viscosity of rye (Secale cereale L.) bread made from endosperm and whole meal flour: Impact of high molecular-weight arabinoxylan, starch and protein // Journal of the Science of Food and Agriculture, 2011, No. 91 (3), P. 469-479.

6. Knudsen K.E.B., Laerke H.N. Rye arabinoxylans: Molecular structure, physicochemical properties and physiological effects in the gastrointestinal tract // Cereal Chemistry, 2010, Vol. 87, P. 353-362.

7. Mendis M., Simsek S. Arabinoxylans and human health // Food Hydrocoll., 2014, No. 42, P. 239-243.

8. Ragaee S.M., Campbell G.L., Scoles G.J., McLeod J.G., Tyler R.T. Studies on rye (Secale cereale L.) lines exhibiting a range of extract viscosities. 1. Composition, molecular weight distribution of water extracts, and biochemical characteristics of purified water-extractable arabinoxylan // J. Agric. Food Chem., 2001, Vol. 49 (5), P. 2437-2445.

9. Ramseyer D.D., Bettge A.D., Craig F.M. Distribution of total, water-unextractable, and water-extractable arabinoxylans in wheat flour mill streams // Cereal Chem.,2011, Vol. 88, No. 2, P. 209-216.

10. Saeed F., Pasha I., Anjum F.M., Sultan M.T. Arabinoxylans and arabinogalactans: a comprehensive treatise // Crit. Rev. Food Sci. Nutr., 2011, No. 51, P. 467-476.

11. Schwarz T., Kuleta W., Turek A., Tuz R., NowickiJ., Rudzki B., Bartlewski P.M. Assessing the efficiency of using a modern hybrid rye cultivar for pig fattening, with emphasis on production costs and carcass quality // Anim. Prod. Sci., 2015, No. 55, P. 467-473.

Пономарева Мира Леонидовна, $\partial-р$ биол. наук, проф., главный научный сотрудник, ТатНИИСХ ФИЦ КазНЦ РАН. Россия.

Пономарев Сергей Николаевич, $\partial-p c .-x$. наук, главный научный сотрудник, ТатНИИСХ ФИЦ КазНЦ РАН. Россия.

Маннапова Гульназ Сулеймановна, канд.с.-х. наук, старший научный сотрудник, ТатНИИСХ ФИЦ КазНЦ РАН. Россия.

Гильмуллина Лилия Фирдависовна, канд. с.-х. наук, старший научный сотрудник, ТатНИИСХ ФИЦ КазНЦ РАН. Россия.

420059, г. Казань, ул. Оренбургский тракт, 48.

Тел.: (432) 77-81-17.

Ключевые слова: озимая рожь; моносахариды; водный экстракт; зерно; шрот; арабиноксиланы.

\section{MONOSACCHARIDE SPECTRUM OF ARABINOXYLANE FRACTION OF WINTER RYE GRAIN OF DIFFERENT GENOTYPES}

Ponomareva Mira Leonidovna, Doctor of Biological Sciences, Professor, Chief Researcher, Tatar Research Institute of Agriculture - Subdivision of the Federal Research Center "Kazan Scientific Center of Russian Academy of Sciences". Russia.

Ponomarev Sergey Nikolaevich, Doctor of Agricultural Sciences, Chief Researcher, Tatar Research Institute of Agriculture - Subdivision of the Federal Research Center "Kazan Scientific Center of Russian Academy of Sciences". Russia.

Mannapova Gulnaz Syleimanovna, Candidate of Agricultural Sciences, Senior Researcher, Tatar Research Institute of Agriculture - Subdivision of the Federal Research Center "Kazan Scientific Center of Russian Academy of Sciences”. Russia.

Gilmullina Liliya Firdavisovna, Candidate of Agricultural Sciences, Senior Researcher, Tatar Research Institute of Agriculture - Subdivision of the Federal Research Center "Kazan Scientific Center of Russian Academy of Sciences". Russia.
Keywords: winter rye; monosaccharide; water extract; grain; meal arabinoxylans

The analysis of the content and monosaccharide composition of the rye meal carbohydrate fraction of different varieties was carried out using high-performance anion-exchange chromatography method. The dominant component was glucose, in approximately equal proportions arabinose, xylose and galactose were detected. Our research has established partial degradation of arabinoxylans and starch at the beginning of water extraction at a temperature of $300 C$ that as a result of the work of exo-enzymes rye grain. Water extracts of meal contain from 52 to $74 \%$ carbohydrates in oligo-and polymeric form. Based on the content of xylose monosaccharide, rye Ogonek, Podarok and Marusenka are characterized as low pentosan, and Tatarskaya 1, Radon and Pamyati Kunakbaev as highly pentosan (9-11 and 14-16 $\mathrm{mg}$ of xylose/ $1 \mathrm{ml}$ of extract, respectively). 